\title{
Corrosion Behavior of Nanocomposite Al-9 wt\% Si Alloy Reinforced with Carbon Nanotubes
}

\author{
Mustafa K. Ismeal* Kharia S. Hassan** Hussian A. Hussian*** \\ ***Department of Mechanical Techniques/ Institute of Technology/Middle Technical University \\ *** Department of Production and Metallurgy Engineering / University of Technology \\ *Email: mustafa@mtu-irq.com
}

(Received 25 January 2016; accepted 16 August 2016)

https://doi.org/10.22153/kej.2017.08.006

\begin{abstract}
An effort is made to study the effect of composite nanocoating using aluminum-9\%wt silicon alloys reinforced with different percentage $(0.5,1,2,4) \mathrm{wt}$ \% of carbon nanotubes (CNTs) using plasma spraying. The effect of this composite on corrosion behavior for AA6061-T6 by extrapolation Tafel test in sea water 3.5wt\% $\mathrm{NaCl}$ was invested. Many specimens where prepared from AA6061-T6 by the dimension (15x15x3)mm as this first set up and other steps include coating process, X-ray diffraction and SEM examination. The results show the CNTs increase the corrosion rate of the nanocomposite coatings with increasing the weight percentage of CNTs within the Al-Si matrix. Al-9wt\%Si coating layer itself has less corrosion rate if compared with both nanocomposite coating and the substrate of AA6061-T6.
\end{abstract}

Keywords: Aluminum-9\%Silicon, AA6061-T6, nanocomposite, CNTs, corrosion, plasma spraying.

\section{Introduction}

The new researches elaborate on aluminiumbased composite found its exhibit many achievable fascinating material properties such as stiffness, wear resistance, specific strength, damping properties with less coefficient of thermal expansion when its compared with the conventional aluminium alloys [1]. Al-Si alloys are used extensively for automobile applications because their high corrosion resistance owing to low density [2]. The addition of carbon nanotubes (CNTs) as reinforcement for metal matrix composite will perform a remarkable enhancement in the physical and mechanical properties [3]. Researches where used carbon to obtain reinforcement of $\mathrm{Al}-\mathrm{Si}$ alloys to achieve combination of high strength and high modulus of elasticity of fiber and high toughness of the matrix [4]. In CNTs where the tensile strength of maximum layer ranged from $11-63 \mathrm{GPa}$ and the Young's modulus variant from 270- $950 \mathrm{GPa}$ [5]. The aluminum has tendency to forming oxide film, thus oxide films protect the aluminum against chloride ion attack [6-8]. Many authors investigate of aluminum corrosion behavior. A corrosion behavior of pure aluminum and aluminum alloy were investigated with salt media compering with other media by Grubač at el. [9]. Also aluminum silicon alloy (Al-9wt\%Si) effects on pitting corrosion when it's immersed in $0.5 \mathrm{M}$ $\mathrm{NaCl}$ solution with current density ( $\mathrm{i}_{\text {corr. }}$ ) equal $0.96 \mu \mathrm{A} / \mathrm{cm}^{2}[10,11]$. Aluminum AA6061-T6 alloy has excellent corrosion resistance with medium mechanical strength, it has the highest strength of the 6000 series alloys. Alloy AA6061T6 is known as a structural alloy. However, this alloy has best resistance to corrosion when the amount of silicon does not exceed the amount of high level which combines with the magnesium content to form MgSi [12]. Gopi and Manonmani, were measured corrosion rate of AA6082-T6 in $3.5 \% \mathrm{NaCl}$ solution media is typically $1.95 \mathrm{mpy}$ and the current density ( $\mathrm{i}_{\text {corr. }}$ ) equals $4.27 \mu \mathrm{A} / \mathrm{cm}^{2}$ [13]. 
In this research, was aimed to study corrosion behavior of Al-9wt\%Si/MWNTs nanocomposite coating materials in sea water with different portion of MWNTs as compared with Al-9wt\% Si alloy its self were investigated.

\section{Experimental}

The base alloys AA6061-T6 are used for many applications as the matrix material, AA6061-T6 where purchased of AALCO Metals Limited, UK. The chemical composition analysis is carried out using the ARL spectrometer instrument as indicated in the Table (1). Many corrosion specimens from base material were prepared in the dimensions of $(15 \times 15 \times 3) \mathrm{mm}$ according to ASTM (G71-31) aluminum 9\%wt silicon powder of particle size 15-70 $\mu \mathrm{m}$ were purchased from Phoenix Scientific Industry Ltd., UK (PSI) High purity of a Multiwall carbon nanotubes (80 wt $\%$ ) (20-70)nm diameter (1-3) $\mu \mathrm{m}$ in length were purchased from ARRY International Group Limited, Germany. XRD and ARL analyses for alloy AA6061-T6 had been done after surface preparation the XRD and electrochemical corrosion test had been done at Ministry of Scientific and Technology, Iraq.

Table 1,

Chemical composition of Al alloy AA6061-T6.

\begin{tabular}{llllllllll}
\hline $\begin{array}{l}\text { Element } \\
\text { wt\% }\end{array}$ & $\begin{array}{l}\text { Si } \\
\text { Max. }\end{array}$ & $\begin{array}{l}\text { Fe } \\
\text { Max. }\end{array}$ & $\begin{array}{l}\text { Cu } \\
\text { Max. }\end{array}$ & $\begin{array}{l}\text { Mn } \\
\text { Max. }\end{array}$ & $\begin{array}{l}\text { Mg } \\
\text { Max. }\end{array}$ & $\begin{array}{l}\text { Cr } \\
\text { Max. }\end{array}$ & $\begin{array}{l}\text { Zn } \\
\text { Max. }\end{array}$ & Ti Max. & Al bal. \\
\hline $\begin{array}{l}\text { Actual } \\
\text { AA6061-T6 } \\
\text { alloy }\end{array}$ & 1.05 & 0.25 & 0.08 & 0.9 & 0.8 & 0.01 & 0.12 & 0.09 & - \\
$\begin{array}{l}\text { Nominal } \\
\text { (Standard) } \\
\text { value of }\end{array}$ & $0.7-1.3$ & 0.5 & 0.1 & $0.4-1$ & $0.6-1.2$ & 0.25 & 0.2 & 0.1 & - \\
AA6061-T6 & & & & & & & & & \\
\hline
\end{tabular}

\section{Preparation of Composite Materials}

The composite materials were prepared by mixing particles of $\mathrm{Al}-9 \% \mathrm{Si}$ wt\%, with carbon nanotubes which added in different percentage $(0.5,1,2,4)$ wt. \% using powder metallurgy technique. The produced composite materials were used for coating the base aluminum alloys AA6061-T6 with about $100 \mu \mathrm{m}$ by using plasma spraying technique with automated robot apparatus. Plasma spray technique which is cold coating process used "plasma" as a source of heat the power (composite powder) where pass through the plasma jet in end of the plasma gun nuzzle. The plasma heat up nearly the powder to mushy state then the particles flight by the compose gases (Argon, hydrogen and helium) to strike on the flat substrate which is AA6061-T6. However, in order to observe the effect of coating layer on corrosion behavior after completing coating, the composite specimens were categorized and sorted into groups as shown in Table (2).

Table 2,

Categorization of Specimens for composite.

\begin{tabular}{ll}
\hline Specimens symbol & State of specimens \\
\hline A & AA6061-T6 base alloy \\
B & As recived Al-9wt\%Si alloy \\
C & Al-9\%Si alloy with $0.5 \mathrm{wt} \%$ CNTs nanocompsite \\
D & Al-9\%Si alloy with $1 \mathrm{wt} \%$ CNTs nanocompsite \\
E & Al-9\%Si alloy with $2 \mathrm{wt} \%$ CNTs nanocompsite \\
F & Al-9\%Si alloy with $4 \mathrm{wt} \%$ CNTs nanocompsite \\
\hline
\end{tabular}

\section{X-Ray Diffraction}

$\mathrm{X}$-Ray diffraction test was investigated on specimens (B, C, D, E, and F) groups of Table (2), and phase analysis results for specimens group are shown in Figure (1). SEM topography and optical microscope (an cross-section) of the coating layer was observed the coating layer in Figure (2). The 
scanning electron microscope (SEM) was used for micrographs of composite specimens as shown in Figure (3) for (B) specimens.

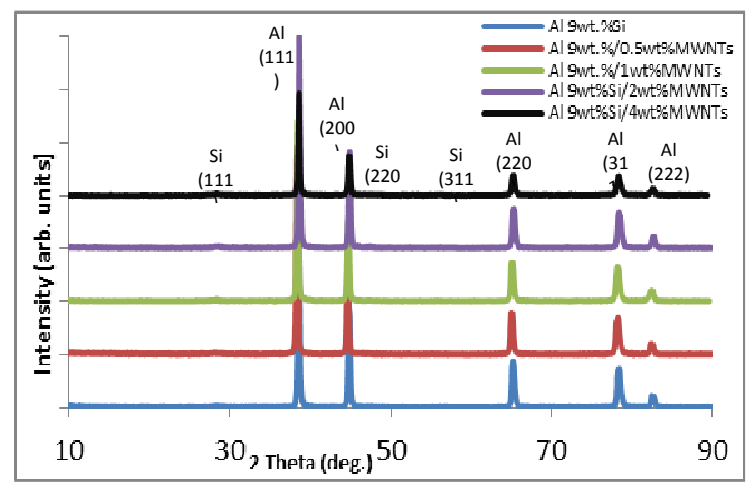

Fig. 1. XRD Phase analysis for Al-SilCNTs nanocomposite coating specimens.
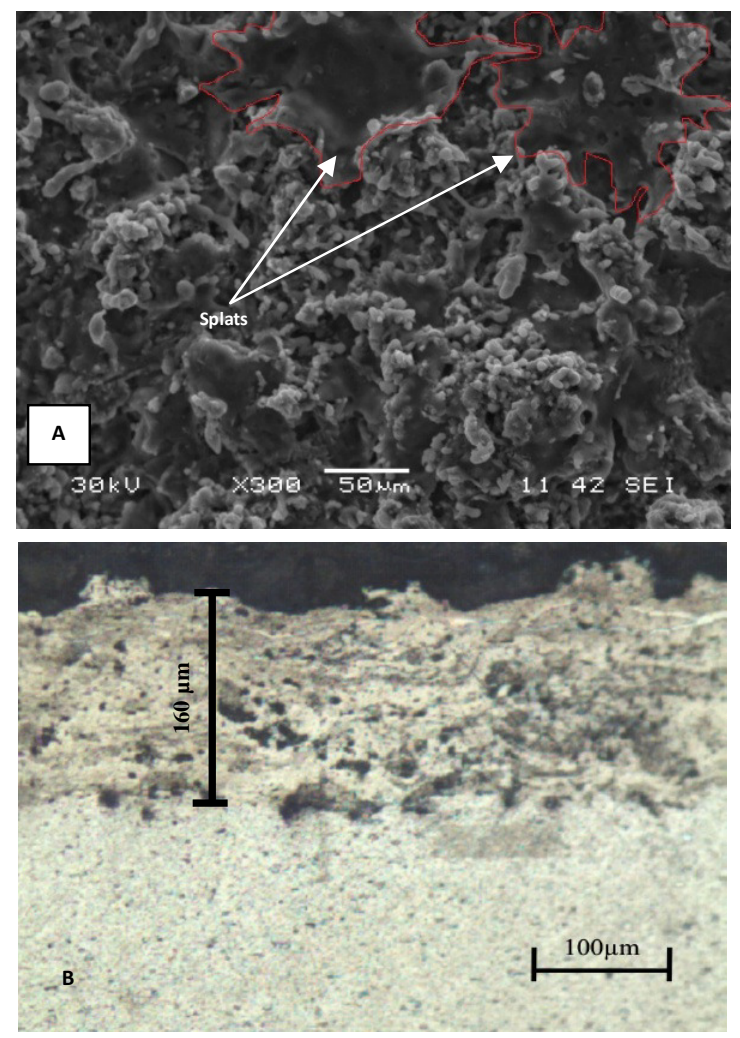

Fig. 2. SEM micrograph show the splat of Al9wt\% Si/0.5wt\% CNTs nanocomposite (A). In the right side (B) show an optical microscope crosssection for previous sample.

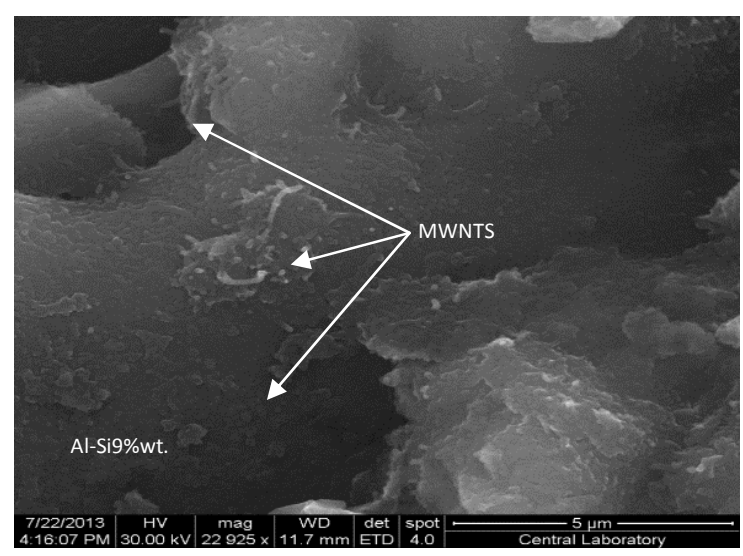

Fig. 3. SEM micrograph of specimens (C) shows MWNTs are embedded in Al-Si matrix.
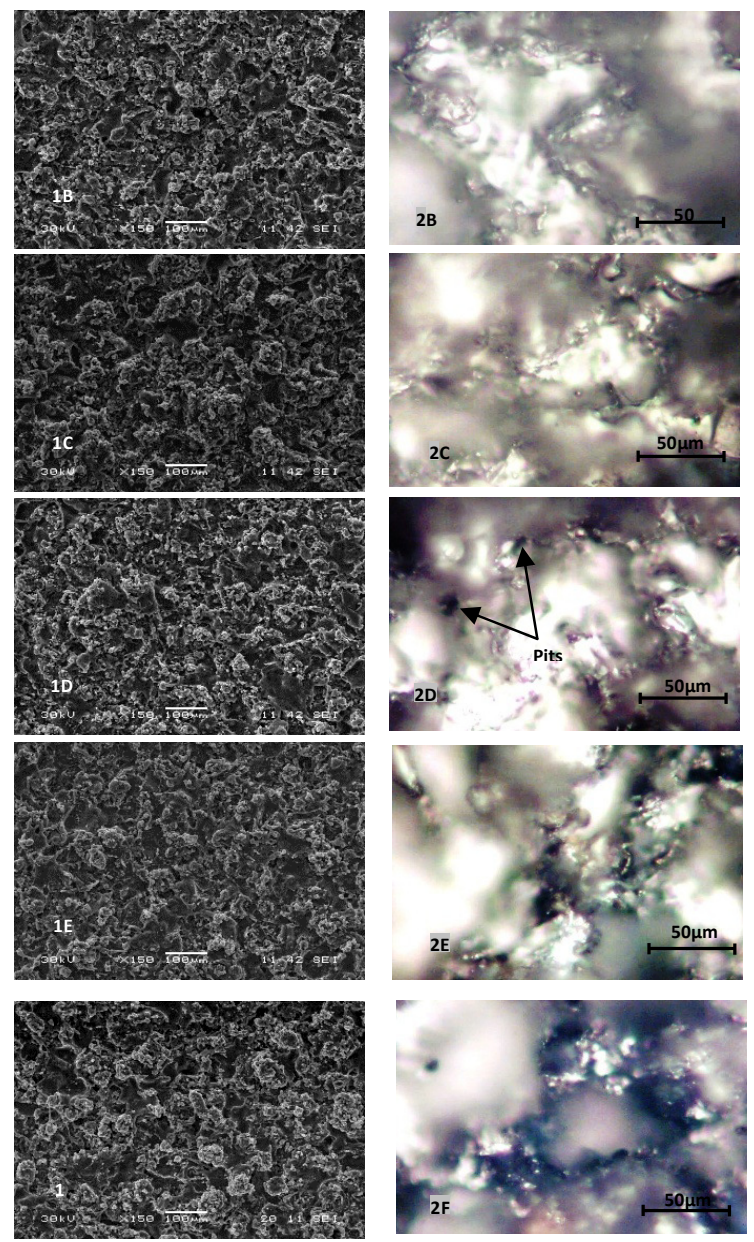

Fig. 4. SEM micrographs of $1 \mathrm{~B}, 1 \mathrm{C}, 1 \mathrm{D}, 1 \mathrm{E}$ and $1 \mathrm{~F}$ specimens before corrosion test on the left-side, Optical micrographs of $2 \mathrm{~B}, 2 \mathrm{C}, 2 \mathrm{D}, 2 \mathrm{E}$ and $2 \mathrm{~F}$ after Tafel test on the right-side. 


\section{Electrochemical Corrosion Test}

Electrochemical corrosion test was implemented by Tafel extrapolation method using a Wenking Mlab multi channels potentiostat and SCI-Mlab corrosion measuring system from Bank Electroniks-Intelligent control $\mathrm{GmbH}$, Germany 2007, this test was carried out at room temperature in Ministry of Science and Technology / Department of Materials as shown in Figure (5).

Tafel equation is used for electrochemical kinetics related to an electrochemical reaction to the over potential. For a single electrode Tafel equation specified as;

$\eta=A \times \ln \left(\frac{i}{i_{0}}\right)$

Where,

$\eta$ is the overpotential

$A$ is Tafle $\mathrm{V}$ plot

$i$ is the current density, $\mathrm{A} / \mathrm{m}^{2}$ and

$i_{0}$ is the so-called "exchange current density", $\mathrm{A} / \mathrm{m}^{2}$.

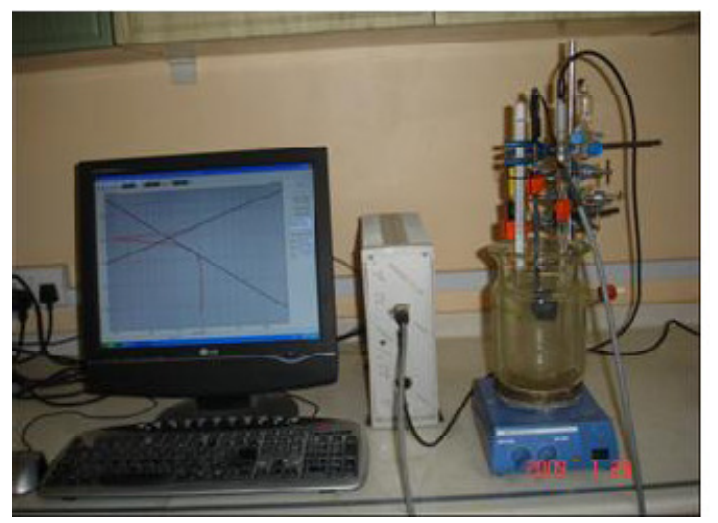

Fig. 5. The electrochemical corrosion unit.

The polarization apparatus measurements were carried out in a corrosion cell having three electrodes of electrochemical cell. The cell contain platinum foil as auxiliary electrode, reference is a saturated calomel electrode (SCE) and working electrode. The AA6016-T6 and AA6016-T6/coated samples was mounted as a working electrode and the exposed area was 10 $\mathrm{cm}^{2}$ for one side. The corrosion solution was amid of $3.5 \mathrm{wt} \% \mathrm{NaCl}$, which done by dissolved $35 \mathrm{wt} \%$ gm. of $\mathrm{NaCl}$ in $1000 \mathrm{ml}$ of distilled water. The $\mathrm{pH}$ meter of solution where measured was found 6.9. High precision $\mathrm{pH}$ meter of $\pm 0.01 \mathrm{PH}, \pm 1 \mathrm{mV}$, $\pm 0.4^{\circ} \mathrm{C}$ model $\mathrm{PH}-2602 \mathrm{PH} / \mathrm{ORP} / \mathrm{Temp}$ Meter was calibrated by using two buffers, $\mathrm{pH} 7$ buffer and
$\mathrm{pH} 4$ buffer. The working temperature was maintained at ambient temperature $\left(25^{\circ} \mathrm{C}\right)$ monitoring by thermometer, there was no significant change of temperature during the procedure. First when the sample mounted in working electrode (WE) the potential difference between working electrode and reference electrode measured the open circuit polarization (OCP) without polarizing the reference electrode. Next step applying potential difference to a preset voltage and force a current through the counter electrode towards the working electrode in order to counteract the difference between preset voltage and existing working electrode potential. In order to apply Tafel equation the tangent line for cathode and anode curve where automatically occur by program fitting. Then the point cross of both two lines express the corrosion current (i corr.). For the cycling the polarized anode curve for period of experiment time will exhibit a loopline due to the breaks down of the protective film. The point of cross loop express as pitting current (i pitt.).

Cell current readings were taken during slow sweep of the potential. The range was taken from $(-100$ to +100$)$ mv relative to $(\mathrm{OCP})$. Scan rate defines the speed of the potential sweep was taken $10 \mathrm{mv} / \mathrm{sec}$. In this range, the current density versus voltage curve is almost nearly linear. In this test, aluminum alloy (AA6061-T6) coating by composite material and uncoated specimens were placed on working electrode W.E. Calomel saturated electrode was immersed in salt solution bath as reference electrode, all samples immersed in $\mathrm{NaCl}$ solution of $3.5 \mathrm{wt} . \%$ which indicate $\mathrm{pH}$ was 6.8. This test is used to find out corrosion parameters, like corrosion potential $\mathrm{E}_{\text {corr. }}$ and corrosion current $i_{\text {corr. }}$ for each specimen, which has amount CNTs in the coating layer. The parameters latter will use to calculate corrosion rate by using C.R equation below [14].

C. $R(m p y)=0.13 \times i_{\text {corr. }} \times E q \cdot \frac{w t}{\rho}$

Where;

C.R(mpy); is milli-inches per year, $i_{\text {corr. }}$; is the corrosion current density $\left(\mu \mathrm{A} / \mathrm{cm}^{2}\right)$, Eq.wt; refers to equivalent weight of the corroding species, $\rho$; is the density of the corroding specimens, $\left(\mathrm{g} / \mathrm{cm}^{3}\right)$. The values for the corrosion potentials and corrosion current densities were estimated from the intersection of the anodic and cathode Tafel lines. The corresponding corrosion potentials $\left(\mathrm{E}_{\text {corr }}\right)$, corrosion current density ( $\left.\mathrm{i}_{\text {corr }}\right)$, anodic listed in Table (3) and Figure (6). 
Table 3,

The results of electrochemical corrosion in sea water.

\begin{tabular}{|c|c|c|c|c|c|}
\hline $\begin{array}{l}\text { Specimens } \\
\text { symbol }\end{array}$ & OCP $[\mathrm{mV}]$ & $\begin{array}{l}i_{\text {corr. }}\left[\mu \mathrm{A} / \mathrm{cm}^{2}\right] \\
\text { SCE }\end{array}$ & $\mathbf{E}_{\text {corr. }}[\mathrm{mV}]$ & $\begin{array}{l}\text { Corrosion rate } \\
{\left[\text { mm.year }^{-1}\right](\mathbf{m} . \mathbf{p . y})}\end{array}$ & $\mathbf{i}_{\text {pitt. }}\left[\mathbf{m A} / \mathrm{cm}^{2}\right]$ \\
\hline A & -848.7 & 10.31 & -858.3 & 4.433 & 1.7 \\
\hline B & -808.4 & 1.12 & -803.3 & 0.481 & 0.6642 \\
\hline $\mathrm{C}$ & -678.7 & 4.65 & -530.7 & 1.999 & 0.6728 \\
\hline $\mathrm{D}$ & -597.6 & 22.57 & -598.4 & 9.705 & 0.6819 \\
\hline $\mathrm{E}$ & -590.1 & 29.43 & -603.1 & 12.654 & 0.7052 \\
\hline $\mathrm{F}$ & -528.7 & 31.5 & -768.2 & 13.545 & 0.9955 \\
\hline
\end{tabular}

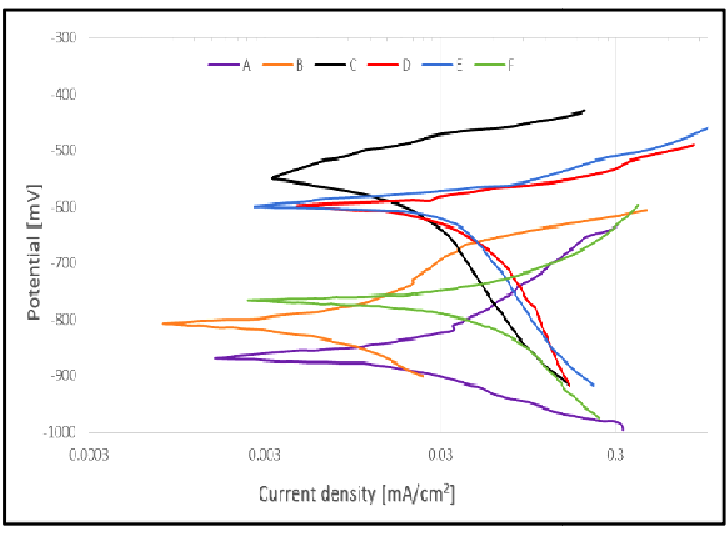

Fig. 6. Electrochemical behavior polarization for all specimens.

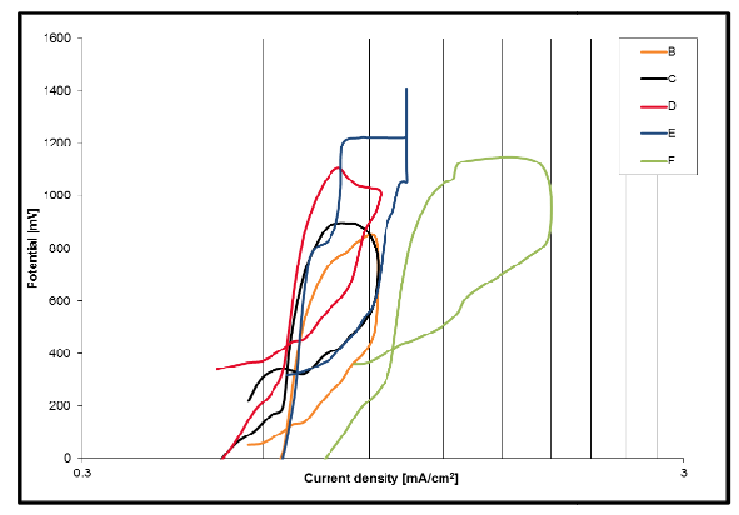

Fig. 7. Electrochemical cycling for coating layers of Al-9wt\%Si/MWNTs nanocomposite.

\section{Discussion}

In the Figure (1) shows the result of X-ray diffraction (XRD) patterns of all specimens in Table (2). According the XRD pattern of $2 \theta$ verses intensity peaks, aluminum and silicon peaks are shown with aluminum peaks (111),(200),(220),(311),(212) plans and silicon (111) plan with very small peaks detected by the XRD program (220) and (311) plans. The MWNTs are not clearly shown in the XRD graphs but its detected by program with slightly small peaks intensities in case of $2 \mathrm{wt} \%$ and $4 \mathrm{wt} \%$ of CNTs, this is due to the small amount of CNTs which is below the detection limit of the X-ray counter and also the dispersion of CNTs in Al$9 \mathrm{wt} \% \mathrm{Si}$ particles so the majority of MWNTs are embedded in the matrix, this confirmed in micrograph shown in Figure (3). In Figure (2-A) SEM micrograph for the topography of the coating layer for specimen (C), its reveals the splat of the coating formation and built up during APS. An optical microscope examination shown in Figure (2-B) for the cross-section of coating layer for APS after etching (HF 0.5 vol. \%, distilled water 95 vol. \%). The coating thickness was measured is between (100- 160) $\mu \mathrm{m}$. In Figure (4) SEM topography image and optical microscope for (B, C, D, E and F) specimens for Al-9wt\%Si plasma spraying coating surface. The coating surface the surface tend to be rough with having pores. Each splats were composed of Al$9 \mathrm{wt} \% \mathrm{Si}$ and MWNTs. The fully melted liquid particles (Al-Si) during flight will form lamella when impacted on the substrate. Thus, a rapid solidification of the splats occurred upon impact due to high cooling rates of the splat. The cooling rate of the splats was reported in the literature as 106 and $107 \mathrm{~K} . \mathrm{s}^{-1}$. The pores are formed between lamellar structures due shrinkage of lamellar cause by rapid solidification of Al-Si. The splats or lamellae formation of Al9wt $\%$ Si $/ 1 \mathrm{wt} \%$ MWNTs composite formed during plasma spraying are rough but the splash fingers are connected. The coating surface has some pores due to shrinkage of splat of aluminum matrix nanocomposite with MWNTs embedded in Al-Si matrix. Some MWNTs have settled on the top surface that could clearly show in Figure (3).

Figure (6) shows the polarization curves of all specimens which categorized in Table (2). These figures sign that the cathodic and anodic polarization curves are similar in the corrosion behavior for the base (AA6061-T6) and composites (Al-9wt\%Si/MWNTs) in $3.5 \% \mathrm{NaCl}$ solution but they are different in the corrosion 
current density and corrosion potential. The potential of corrosion depends on the electrochemical behavior and the quantity of alloying elements such as silicon and magnesium in Table (3) specimen (A) has a corrosion potential of $-858.3 \mathrm{mV}$ and a corrosion current of $10.31 \mu \mathrm{A} / \mathrm{cm}^{2}$ and the corrosion rate is 4.433 m.p.y. The corrosion is taken place due to the presence of chloride ions which released and combine with hydrogen to formed hydraulic acid. The hydrochloric acid increase corrosion rate accelerated by elements are presence in the microstructure. The corrosion behavior in specimens (B) gives low corrosion rate comparing with specimens (A), this is due to combine and encourage of boundaries between the of Al-rich $(\alpha)$ phase and silicon particles in refined microstructures, since such boundaries are more sensitive to the corrosion action .

From Table (3), it was seen that a nanocomposite with in specimens $(\mathrm{D}, \mathrm{E}$ and $\mathrm{F})$ has high corrosion current density (high corrosion rate) than that nanocomposite with (B and $\mathrm{C}$ ) this would refer the MWNTs has play role of increasing corrosion rate by localized pitting corrosions because the CNTs behave as negative (more noble) than the alloy content. This explained by Aung et al. [15] where microgalvanic action between the cathodic CNTs and the anodic of elements less corrosion resistance in the matrix in $3.5 \mathrm{wt} \% \mathrm{NaCl}$. More than 2wt of MWNTs in the Al-9wt\%Si will tend to be agglomerated, therefore the ion exchanged will reduced, as well as high porosity which a accompanied of high MWNTs contents will make the corrosion more faster. Matrix which reduces the cathodic areas to localized regions such as impurities, porosities and reinforcements in the alloy matrix. The specimen (C) gives lower corrosion rate due to less amount reinforcement (MWNTs), but the still Al-Si protective coating layer (specimen B) without adding reinforcement has less corrosion rate. Figure (7) shows the electrochemical cycling corrosion, in this figure revels the pitting where start for coated samples almost closes each other but in table (3) the $i_{\text {pitt. }}$ Are increases with respect of amount MWNTs that's confirmed the MWNTs breaking down the coating layer by accelerating the pitting corrosion.

\section{Conclusion}

1. Corrosion tests results have shown that $\mathrm{Al}$ alloy $9 \%$ silicon samples tend to yield lower corrosion rate than AA6061T-6 alloy in 3.5 $\mathrm{wt} \% \mathrm{NaCl}$ solution.

2. The external appearance $s$ of the cathodic and anodic members of the deposit Al-9wt\% Si alloy sample depict representative pitting reactions, differently to that exhibited for composite specimens .

3. Nanocomposite with $0.5 \mathrm{wt} \%$ MWNTs shows lower corrosion rate if compared with other constitute nanocomposite, this refers to the CNTs would enhanced pitting corrosion rate.

\section{References}

[1]Jailani, H. Siddhi, A. Rajadurai, B. Mohan, A. Senthil Kumar, and T. Sornakumar. "Multiresponse optimisation of sintering parameters of Al-Si alloy/fly ash composite using Taguchi method and grey relational analysis." The Int. J. of Adv. Manu. Tech. Vol.45, No. 3-4, 2009.

[2]Hemanth, Joel. "Tribological behavior of cryogenically treated $\mathrm{B} 4 \mathrm{Cp} / \mathrm{Al}-12 \% \quad \mathrm{Si}$ composites." Wear Vol. 258, No. 11, 2005.

[3]Tjong S.C, 'Carbon nanotube reinforced composites, Metal and ceramic matrices', Wiley-VCH Verlag GmbH \& Co. KGaA, Weinheim, Germany, 2009.

[4][4] Y. Qiurong, L. Jinxu, Li. Shukui, W. Fuchi, W. Tengteng, Fabrication and mechanical properties of $\mathrm{Cu}$-coated woven carbon fibers reinforced aluminum alloy composite, Materials and Design, Vol.14, 2014, pp. 442-448.

[5] Y. Min-Feng, O. Lourie, M.J. Dyer, K. Moloni, T.F. Kelly, R.S. Ruoff, Strength and breaking mechanism of multiwalled carbon nanotubes under tensile load, Science, Vol. 287, 2000, pp. 637-640.

[6] Vrsalović, Ladislav, Maja Kliškić, and Senka Gudić. "Application of phenolic acids in the corrosion protection of $\mathrm{Al}-0.8 \mathrm{Mg}$ alloy in chloride solution." Int. J. Electrochem. Sci. Vol 4, 2009, pp.1568-1582.

[7] Amin, Mohammed A., Hamdy H. Hassan, Omar A. Hazzazi, and Mohsen M. Qhatani. "Role of alloyed silicon and some inorganic inhibitors in the inhibition of meta-sTable and sTable pitting of $\mathrm{Al}$ in perchlorate solutions." J. of app. Electrochemistry, Vol. 38, No. 11, 2008, pp.1589-1598.

[8]Badawy, W. A., F. M. Al-Kharafi, and A. S. El-Azab. "Electrochemical behaviour and corrosion inhibition of $\mathrm{Al}, \mathrm{Al}-6061$ and $\mathrm{Al}-\mathrm{Cu}$ in neutral aqueous solutions." Corrosion Science, Vol. 41, No. 4, 1999, pp. 709-727. 
[9] Grubač, Zoran, Ranko Babić, and Mirjana Metikoš-Huković. "Application of substituted $\mathrm{N}$-arylpyrroles in the corrosion protection of aluminium in hydrochloric acid." J. of app. Electrochemistry, Vol. 32, No.4, 2002, pp. 431-438.

[10] Eid, Salah, M. Abdallah, E. M. Kamar, and A. Y. El-Etre. "Corrosion inhibition of aluminum and aluminum silicon alloys in sodium hydroxide solutions by methyl cellulose.", J. Mater. Environ. Sci. Vol. 6, No. 3, 2015, pp. 892-901.

[11] Wislei R. Osório, Noé Cheung, Leandro C. Peixoto and Amauri Garcia, "Corrosion Resistance and Mechanical Properties of an Al 9wt\%Si Alloy Treated by Laser Surface Remelting", Int. J. Electrochem. Sci., Vol. 4, 2009, pp. $820-831$.

[12] AFSA, Pocket Guide 3, "Corrosion Resistance of Aluminium and Protective Measures Where Appropriate", 1st edit., AFSA Compiled and publisher, South Africa, 2011. H. S. Patill, S. N. Soman, "Corrosion Behaviour of Friction Stir Welded Aluminium Alloys AA6082-T6", Amr. J. of
Mat. Eng. and Tech., Vol. 2, No. 3, 2014, pp. 29-33.

[13] S. Gopi and K. Manonmani, "Microstructure and mechanical properties of friction stir welded 6082-T6 aluminium alloy", Aus. J. of Mech. Eng., Vol. 11, 2013, pp. 131-137.

[14] Annual Book of ASTMSTANDARDS, Standard Practice for Calculation of Corrosion Rates and Related Information, G102-89,Vol. 03.02, 2004.

[15] Naing Naing Aung, Wei Zhou, Chwee Sim Goh, Sharon Mui Ling Nai and Jun Wei, "Effect of carbon nanotubes on corrosion of Mg-CNT composites", Corrosion Science 52 (2010) 1551-1553. 


\title{
سلوك التآكل لسبيكة الالمنيوم ـ سيليكون ( Al-9wt\% Si) المقواة مع الانابيب النانوية CNTs
}

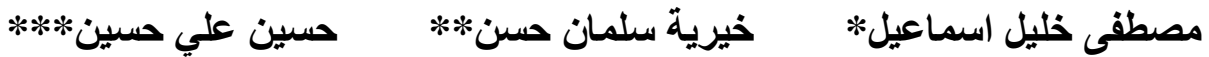

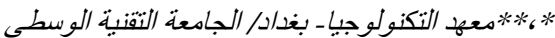

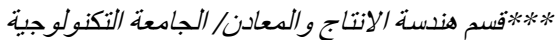 \\ mustafa@mtu-irq.com البريد الالكتروني:
}

الخلاصة

في هذه الدراسة تم بيان تاثثير استخدام انابيب الكاربون النانوية في المواد المتراكبة النانوية من

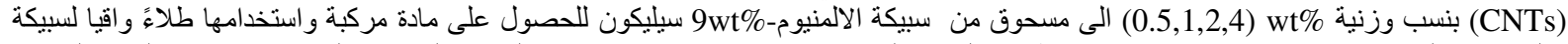

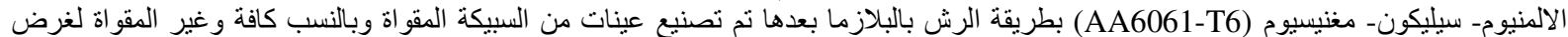

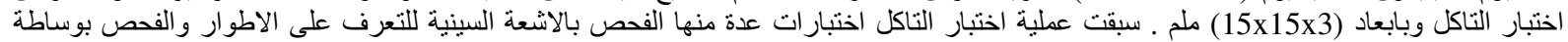

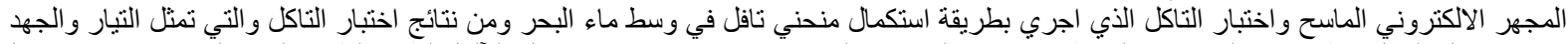

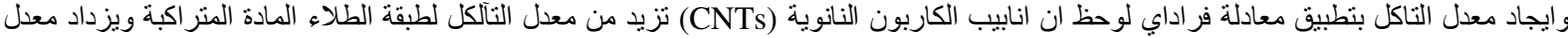

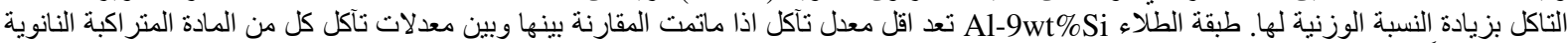

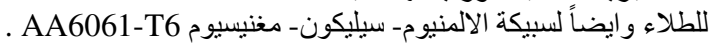

